\section{Abstractions}

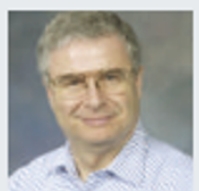

\section{PROJECT LEADER}

Studying asocial insect

such as the honeybee

requires asocial approach. George Weinstock from the Human Genome Sequencing Center at Baylor College of Medicine

in Houston, Texas, drew on the skills of 174 collaborators to analyse the bee's molecular features and gene content. The group found tantalizing hints about how bees manage their societies - such as genes for nursing and gathering pollen - but no clear-cut drivers of social organization (see page 931). Weinstock told Nature about his genetic hunt for animal behaviour.

What was the biggest surprise about the bee's genome?

That wedid not come up with breakthroughs in understanding social behaviour of the bee. Many small changes account for this and it is possible that this reflects our limited knowledge of behavioural genetics.

You have sequenced the genomes of humans, wasps, sea urchins, slime mould and bacteria. Which was the most fun? They all have their own beauty and fascination. The human genome was our grail and accomplishing thatstill sends chills down my spine. Bacterial pathogens are amazing because once you have the sequence, you can apply the awesome power of bacterial genetics to dig deeper into a bacterium than anyother organ ism.

How will your sequences contribute to personal ized medicine in the future? They will have a big pay-off. First wewere part of decoding the human genome reference sequence. Next was the HapMap project sampling human diversity. Now we arescaling up for human mutation and disease-gene discovery. These activities will form the bedrock for personalized medicine.

What are you doing with the human genome? We are shifting the emphasis from deciphering whole genome sequences of an imals to human mutation and diseasegene dis covery. We will tackle as many diseases as possible in the next few years, from cancer to psychiatric disorders.

What is the future of gen ome sequencing? First, there is a need for more DNA sequencing than ever before. Having the human genome sequence was not the end -it provided the reference against which other human genomes can be compared for an alysing disease. Given the large number of diseases that are being studied, the amount of sequencing is huge. Second, new sequencing technologies are just coming to market, offering greater capacity at lower cost, and this should have adramatic effect.

\section{MAKING THE PAPER}

Tanja Woyke

\section{Genomes, in microbes, in worms, in mud, in the Mediterranean.}

For most bench-bound postdocs, travelling to Italy and diving in the Mediterranean sounds like a dream holiday. But for Tanja Woyke, a fellow with Edward Rubin at the US Department of Energy Joint Genome Institute (JGI) in Walnut Creek, California, the trip marked the glamorous beginning to an arduous project in metagenomics.

The allure ended with the samples Rubin sent her to collect - a silt-dwelling gutless worm called Olavius algarvensis. Rubin became interested in this worm at a meeting in Monterey, California. He was interested in metagenomics - sequencing genomes from multiple microbes present in environmental samples. Although most environments contain thousands of microbial species, he sought a simpler problem. He found one when he heard a talk by Nicole Dubilier of the Max Planck Institute for Marine Microbiology in Bremen, Germany. He realized the marine worm she studied was ideal because only a handful of microbes were associated with it.

After visiting Dubilier in Bremen and offering the JGI's genomic sequencing clout, Rubin found that the frozen samples the German lab had collected weren't fit for sequencing, because the microbial and the worm DNA stuck together. ${ }^{\alpha}$ We tried everything we could to separate and sequence the samples, but we failed," says Woyke.

So Woyke flew to Elba and spent two weeks searching for the worms, which are about two centimetres long, in the mud off the Capo di Sant' Andrea. She stirred up the sea bed and looked for tiny white organisms to "ball up". Whenever she found lots of these balls, she collected buckets of sediment and carried them ashore. Every evening, she searched through 32 litres of silt, separating the worms from the

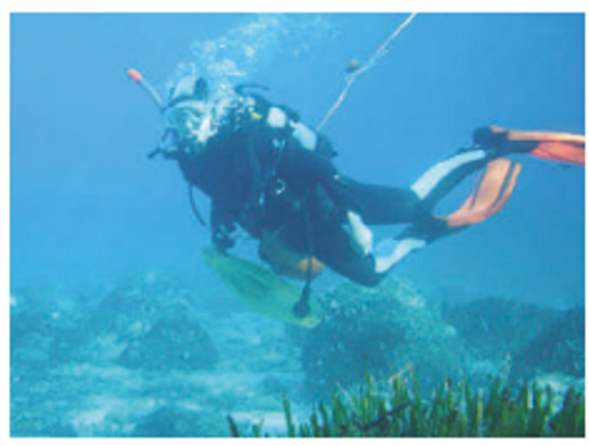

dirt with a pipette. She eventually found several thousand worms, sent 300 back alive on ice, and froze the rest. "I had to pick through a lot of worms, "Woyke says. "It was very tedious."

Tedious or not, Woyke's efforts paid off; although the frozen worms were easier to package and ship, the fresh ones proved more useful. The JGI group separated the microbial DNA from the fresh worm DNA, and sequencing the microbial DNA proved much easier than collecting the worms.

The team completed four microbial genomes. Woyke then travelled to Bremen to help identify the genes and metabolic pathways in these genomes. Dubilier suspected that this information would explain how the microbes helped the worms to digest food and excrete waste. Their genomic analysis (see page 950) showed that the worm outsources activities to the microbes that its ancestors, which had a gut and a renal system, would have done themselves.

The project helped the team understand how metagenomics can explain the biological capabilities of a simple microbial community. The JGI team is now applying these methods to larger, more complicated systems. And Rubin says that he can use pictures of Woyke's fieldwork for both public relations and recruiting. "Many of the projects we work on are connected to environments you wouldn't choose for a vacation - like looking for microbes where acid mine run-off is present," says Rubin. "I am really pleased I can show pictures of Tania in Elba skin-diving - even if it is for worms."

\title{
KEY COLLABORATOR
}

Seven years ago, French geochemists Francois Robert of the National Museum of Natural History in Paris and Marc Chaussidon of the Center for Petrographic and Geochemical Research in Vandoeuvre-lès-Nancy began studying rocks to leam more about the temperature of ancientoceans.

The researchers analysed silicon isotopes in a variety of ancient sediments from Australia, Africa and China.
Changes in the silicon isotope composition over time showed that, over the period from 3.5 billion to 0.8 billion years ago, seawater temperatures dropped from about $70^{\circ} \mathrm{C}$ to about $20^{\circ} \mathrm{C}$.

Previous analyses of oxygen isotopes have given the same result. But some researchers contend that oxygen isotopes are a poor indicator because hot water is likely to change them. Silicon isotopes, however, should be more resilient, as water contains oxygen but very little silicon.

Recognizing the need for more robust results, Robert and Chaussidon decided to delay publication. Over the next few years, they continued their analysis and improved thetechnique. They confirmed their results, as reported on page 969 . But this is not the final word. Chaussidon says he expects the controversy to continue, and plans fur ther silicon isotope studies. 